\section{Factors Associated to the Cicatrization Success of Lower- Limb Ulcer of Venous Etiology}

\author{
Rusbert Fernando Álvarez-Del-Río'
}

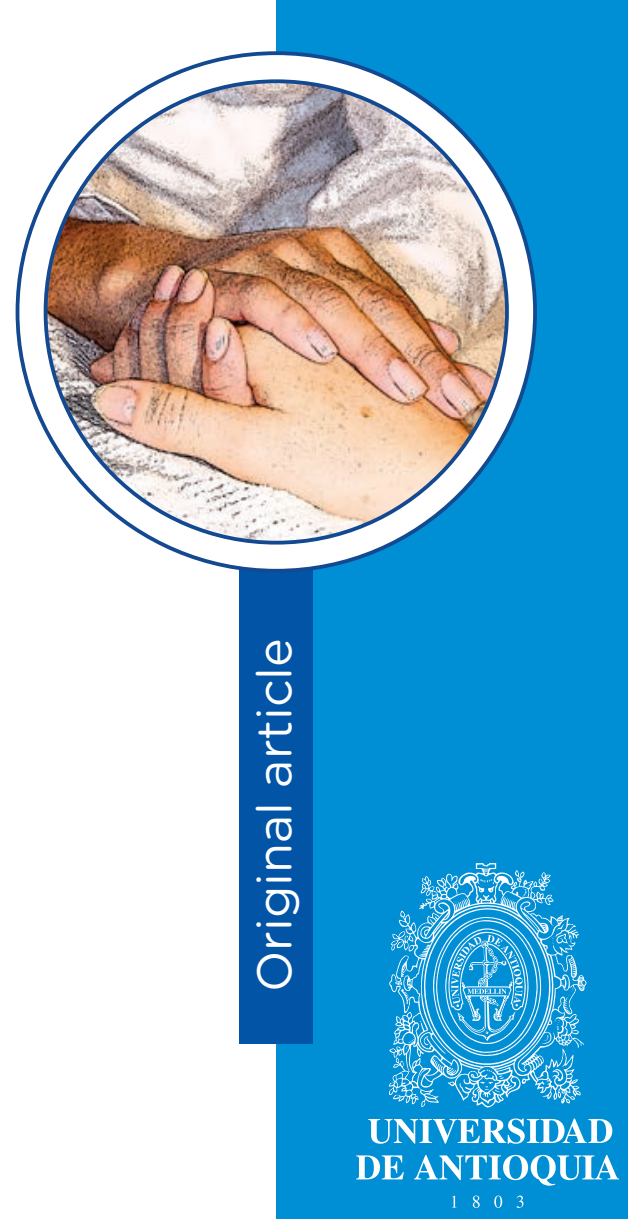

1 Nurse, M.Sc. Professor, Universidad de Antioquia, Medellín (Colombia).

email: rusbert.alvarez@udea.edu.co

Conflicts of interest: none.

Received: August 1st, 2018.

Accepted: September 19th, 2018.

Article linked to research: Factores asociados a cicatrización de úlceras venosas de miembros inferiores de adultos, Medellín, 2014

How to cite this article: Álvarez-Del-Río RF. Factors Associated to the Cicatrization Success of Lower-Limb Ulcer of Venous Etiology. Invest. Educ. Enferm. 2018; 36(3):e08.

DOI: 10.17533/udea.iee.v36n3e08 characterized and the clinical characteristics of the wounds evaluated with the Resvech 2.0 scale. Results. The work showed that $48.7 \%$ of the patients $(52.5 \%$ of the women and $38.1 \%$ of the men) had cicatrization success of the lesion during a maximum time of 90 days. The Cox proportional risk model showed that cicatrization time was higher in patients belonging to low socioeconomic level $(H R=2.0)$, with lesions of greater compromise $(H R=$ $2.7)$, and who were treated by nurses with experience $<5$ years $(H R=2.1)$. Conclusion. The factors associated with

\section{(9) $(\Theta \Theta($}


cicatrization success of ulcers of venous etiology are: belonging to socioeconomic levels above two (on a scale from 1 to 6 ), with a slight lesion, and the nursing staff treating the patient having five or more years of experience in the treatment of wounds. Promotion should take place for nurses to be trained on these themes and on improving their expertise, given that this is a factor that can be modified and which indicates the success of the cicatrization of these lesions.

Descriptors: varicose ulcer; risk factors; prospective studies; wound healing; survival analysis; nursing care.

\section{Factores asociados al éxito de la cicatrización de úlceras de la extremidad inferior de etiología venosa}

Objetivo. Establecer la relación entre los factores sociodemográficos y clínicos con el éxito en la cicatrización en pacientes con úlceras de la extremidad inferior de etiología venosa (UEV). Métodos. Estudio de cohorte prospectivo, multicéntrico con participación de 80 pacientes con UEV, evaluados en tres clínicas de la ciudad de Medellín (Colombia). Se caracterizaron las condiciones sociodemográficas y se evaluaron las características clínicas de las heridas con la escala Resvech 2.0. Resultados. El $48.7 \%$ de los pacientes $(52.5 \%$ de las mujeres y el $38.1 \%$ de los hombres) tuvieron éxito en la cicatrización de la lesión en un tiempo máximo de 90 días. El modelo de riesgos proporcionales de Cox mostró que el tiempo de cicatrización era mayor en los pacientes pertenecientes a estrato socioeconómico bajo $(H R=2.0)$, con lesiones de mayor compromiso $(H R=2.7)$ y quienes fueron tratados por enfermeros con experiencia menor de 5 años $(H R=2.1)$. Conclusión. Los factores asociados al éxito en la cicatrización de las úlceras de etiología venosa son: pertenecer a estratos socioeconómico mayor de dos, que la lesión sea leve y que el personal de enfermería que trata al paciente tenga cinco y más años de experiencia en tratamiento de heridas. Debe promoverse la capacitación de enfermeras en estos 
temas y la mejoría de la experticia, por ser este un factor que puede ser modificable y que apunta al éxito de la cicatrización de estas lesiones.

Descriptores: úlcera varicosa, factores de riesgo, estudios prospectivos; cicatrización de heridas; análisis de supervivencia, atención de enfermería.

\section{Fatores associados ao sucesso da cicatrização das úlcera do membro inferior de etiologia venosa}

Objetivo. Estabelecer a relação entre os fatores sócio-demográficos e clínicos com o sucesso na cicatrização em pacientes com úlcera do membro inferior de etiologia venosa. Métodos. Estudo de coorte prospectivo, multicêntrico com participação de 80 pacientes com UV, avaliados em três clínicas de feridas da cidade de Medellín (Colômbia). Se caracterizaram as condições sócio-demográficas e se avaliaram no tempo as características clínicas das feridas com a escala Resvech 2.0. Resultados. $48.7 \%$ dos pacientes $(52.5 \%$ das mulheres e $38.1 \%$ dos homens) tiveram sucesso na cicatrização da lesão em um tempo máximo de 90 dias. 0 modelo de riscos proporcionais de Cox mostrou que o tempo de cicatrização era maior nos pacientes pertencentes a baixo estrato socioeconómico $(H R=2.0)$, com lesões com maior compromisso $(\mathrm{HR}=2.7)$ e que foram tratados por enfermeiros com experiência menor de 5 anos $(H R=2.1)$. Conclusão. Os fatores associados ao sucesso na cicatrização das úlceras de etiologia venosa são pertencer a estratos socioeconómico maior a dois, que a lesão seja leve e que a enfermeira que trata ao paciente tenha 5 ou mais anos de experiência. Deve promover-se a capacitação de enfermeiras nestes temas e na melhora da experiência, por ser este um fator que pode ser modificável e que aponta ao sucesso da cicatrização destas lesões.

Descritores: úlcera varicosa; fatores de risco; estudos prospectivos; cicatrização; análise de sobrevida; cuidados de enfermagem. 


\section{Introduction}

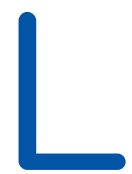

ower-limb ulcer of venous etiology (UVE) is a chronic disease evidenced by trophic lesions of the skin and the subcutaneous cell tissue, originated as consequence of the endogenous affection induced and maintained by high venous pressure. It is of frequent appearance, with preference for the elderly and occurs much more than that of ischemic or neuropathic type. It is defined as "a solution of cutaneous coverage continuity with loss of substance, which exposes the underlying tissues to a variable depth, related etiologically with a venous pathology determinant of ambulatory hypertension in the lower limbs, with scarce tendency to spontaneous cicatrization, chronic evolution, and high tendency to recurrence". (1) The UVE can be varicose, postphlebitic or post-thrombotic or through combination of these, ${ }^{(2)}$ localized generally below the knee, almost always perimalleolar. The lesion denotes histological and structural changes of the vascular and lymphatic wall. These modifications produce physiological alterations, like capillary leak, fibrin deposition, sequestration of leukocytes and erythrocytes, thrombocytosis, and inflammation, which harms oxygenation of the skin and nearby tissue, favoring tissue hypoxia. ${ }^{(3)}$

Care of patients suffering from UVE requires an evaluation and specialized treatment and, on occasion, interdisciplinary due to the multi-causal origin, manifestations on skin, cardiovascular compromise, magnitude and consequence of the damage. Besides the bodily affection, it compromises the quality of life of those who suffer it in the emotional, spiritual, social, and aesthetic dimensions, ${ }^{(4)}$ specifically due to issues associated to constant pain, deterioration of the bodily image, isolation, and difficulty in performing daily living activities. Furthermore, no care or deficient approach generate increased costs due to loss of working capacity, constant institutional readmissions, and high expenditures of health resources, in addition to the possible recurrence if efficient measures are not interposed.

Diverse risk factors have been described that favor the appearance of the wound; among them, those inherent to the physiopathology. ${ }^{(5-7)}$ Fukaya and Margolis ${ }^{(8)}$ consider, among others, immobility, obesity, rigidity of the ankle and deterioration of the calf muscle pump, which facilitate the appearance of varicose veins compromising blood irrigation systems. Some authors ${ }^{(9)}$ hold that the most common factors are advanced age, family background of venous disease, increased body mass index, smoking, antecedents of traumatism, and prior venous thrombosis; they have also considered the patient's social history through characteristics of age, education, occupation, income, postural positions maintained, and access to care. ${ }^{(10)}$

Regarding its epidemiology, between $70 \%$ and $80 \%$ of lower-limb ulcers are of venous etiology. ${ }^{(11,12)}$ Pannier and Rabe ${ }^{(13)}$ found in the general population between 18 and 79 years of age a prevalence of $0.6 \%$ of healed UVE and 
$0.1 \%$ of active wounds. The National Conference on Consensus of lower-limb ulcers ${ }^{(11)}$ reports a population prevalence between $0.5 \%$ and $0.8 \%$ with an annual incidence between 2 and 5 cases for every 1000 people/year. With respect to its chronicity, it is estimated that between $40 \%$ and $50 \%$ of the wounds remain open or active for a period no less than 6 or 12 months; additionally, average times of recurrence of 42 weeks have been found, with an incidence of $22 \%$ of recurrence at three months, 39\% at six months, $57 \%$ at 12 months, and $78 \%$ at three years. ${ }^{(14)}$ For the Latin American population no reliable data is available on its incidence or prevalence, but it is estimated that the latter can be between $3 \%$ and $6 \% .^{(1)}$ In Colombia, within a population prevalence of wounds of $5.2 \%$, the UVE correspond to $14.6 \%$ of that value. ${ }^{(15)}$ Information is still scarce about UVE in the regional and national contexts, which is why we must advance on the description of the chronic process of these lesions.

The objective of this study was to establish the relationship between the sociodemographic and clinical factors with cicatrization success in patients with UVE. This study is important for the nursing profession because, in our context, nurses are responsible for providing care to patients who suffer it and knowledge of the factors related with the UVE cicatrization process will contribute to promoting interventions that lead to the decrease of its presentation and recurrence.

\section{Methods}

A cohort type, prospective observational study was conducted with the participation of 80 patients with UVE who were monitored for up to 13 months. The sampling was non-probabilistic, intentional. Selection of participants was conducted in three clinics in the city of Medellín (Colombia) with specialized nursing care in treating vascular wounds. The study included patients with controlled chronic pathologies, without neurological compromise, with diagnosis of varicose and traumatic UVE by a physician or by a nursing professional specialized in wounds. All the participants had at least one wound complying with the classification criteria of venous classification, according to ultrasound record or clinical diagnosis - in case the patient had more than one UVE, the decision was made to evaluate and monitor the bigger wound and its satellite wound. The study excluded patients with presence of mixed ulcer, those in which there was no certainty that their diagnosis corresponded to UVE, those who abandoned treatment, and those showed intolerance with the use of compression bandage (treatment received). Every patient identified as potential participant was invited to partake in the study and was explained the reasons and benefits; none denied participation.

Information was gathered between September 2014 and October 2015. It was possible to observe the evolution of the UVE, considering at least five observation times (TO -basal-, T1, $\mathrm{T} 2, \mathrm{~T} 3$, and T4), with a difference of no less than 25 days between one evaluation and the other. The wound nurse at the clinic performed all the evaluations and healing, and used different technological dressings according to the wound's cicatrization stage; nevertheless, all the patients received compression bandages as part of the common treatment during follow up. To evaluate the stage and evolution of the UVE, the treating nurse along with the researcher applied the Resvech 2.0 instrument, ${ }^{(16)}$ a scale that measures improvement in the cicatrization process from 0 to 35, with the lowest scores indicating improvement. When tabulating the information from the instrument, infection and inflammation characteristics were recorded individually. To compare differences in cicatrization according to wound size, these were considered small when measuring $\leq 15.9 \mathrm{~cm}^{2}$, medium from 16 to 63.9 $\mathrm{cm}^{2}$, and large from $64 \mathrm{~cm}^{2}$ and above.

For the statistical management of the data, a univariate analysis was used to calculate the frequency distributions of qualitative-type variables and for data of quantitative nature, normality tests were conducted with the statistical 
distribution function through the KolmogorovSmirnov test with Lilliefors correction. The survival analysis considered as result variable the cicatrization success, which was defined as the complete cure of the wound in a time $\leq 90$ days, evidenced by the presence of intact healed skin, absence of edges and absence of wound exudate. The model included those variables complying with statistical significance, biological plausibility or according to the Hosmer-Lemeshow criterion $(p \leq 0.25)$. Censored data corresponded to five patients who quit the study, and four who - upon ending the study - did not achieve cicatrization.

To estimate cicatrization in function of time, the Kaplan-Meier method was used and the Logrank test was used for hypothesis contrast in comparison of two or more groups. The independent variables were dichotomized to define their input to the proportional risk model, thus: compromise of the wound Resvech score: slight $=\leq 15$ points and high $=>15$; nurse experience in wound clinic: $\geq 5$ years and $<5$ years; socioeconomic level: low $=\leq 2$ and high $=3$ and more; age of patient: $\leq 65$ years and 66 and more years. The model also included the variables of gender and time in days since the appearance of the ulcer due to the clinical importance they represented. The Cox proportional risk model was carried out to study the multivariate effect on cicatrization over time. The statistical software used to process the information was Stata v.12.0. The research was approved by the Ethics and Research committees of the National Faculty of Public health at Universidad de Antioquia and of the three clinics where the data were collected. All participants signed the informed consent.

\section{Results}

The study evaluated 80 patients with UVE. All had at least one UVE, with a median of six months of antiquity. Table 1 shows the general characteristics of the participants. There was prevalence of female participants, married, low socioeconomic level, low schooling, and housekeeper as occupation. The mean age for this group was 65 years (minimum $=18$ and maximum $=90$ ). In life habits, there was higher frequency of tobacco consumption than alcohol, poor consumption of fruits and vegetables, high intake of beef and pork, as well as poor engagement in physical activity.

The $62.5 \%$ of the participants were treated by a nurse with experience of five and more years in wound clinic; $55 \%$ of the participants had a relative in charge of home care. It was evidenced that $73.8 \%$ had weight alterations; additionally, $77.5 \%$ suffered hypertension; $53.8 \%$ had a Yao index between 0.7 and 1.30. The most frequent antecedent was that of suffering from varicose veins $(86.3 \%)$, followed by arterial hypertension (63.7\%). Additionally, it was found that $66.3 \%$ of the participants had already had an episode of UVE; inclusively, 19 people had had more than three recurrences. In all, 39.6\% manifested that these wounds had healed in $\leq 4$ months. The most frequent location of the current wound was the internal malleolar (33.7\%), with prevalence of the lower left limb (58.8\%) (Table 2).

Table 3 shows information of the UVE during basal evaluation. It was found that $60 \%$ of these wounds measured less than $16 \mathrm{~cm}^{2}$; the greatest affection occurred in the epidermis (77.5\%), defined edges were present in $63.7 \%$, slough was found in the wound in $51.2 \%$, and $31.2 \%$ had saturated exudate. Infection and inflammation characteristics showed that the wound caused pain (95\%), with erythema and perilesional edema $(82.5 \%$ and $88.7 \%$, respectively). Likewise, other characteristics were found, like presence of wound that did not diminish in size in $92.5 \%$ and wound that increases in size in $81.2 \%$ of the patients. 
Table 1. General characteristics of 80 patients with diagnosis of ulcer of venous etiology

\begin{tabular}{|c|c|}
\hline Variables & Value \\
\hline \multicolumn{2}{|l|}{ Sociodemographic characteristics } \\
\hline \multicolumn{2}{|l|}{ Gender; $n(\%)$} \\
\hline Female & $59(73.8)$ \\
\hline Male & $21(26.2)$ \\
\hline Age in years; average $\pm \mathrm{SD}$ & $65.3 \pm 14.34$ \\
\hline \multicolumn{2}{|l|}{ Marital status; $n(\%)$} \\
\hline Single & $13(16.3)$ \\
\hline Married/common law & $42(52.5)$ \\
\hline Widowed/separated & $25(31.2)$ \\
\hline \multicolumn{2}{|l|}{ Socioeconomic level; $n$ (\%) } \\
\hline 1 and 2 & $50(62.5)$ \\
\hline 3 and more & $30(37.5)$ \\
\hline \multicolumn{2}{|l|}{ Schooling; $n(\%)$} \\
\hline None & $20(25)$ \\
\hline Basic Primary & $42(52.4)$ \\
\hline Basic Secondary & $9(11.3)$ \\
\hline Technical/university & $9(11.3)$ \\
\hline \multicolumn{2}{|l|}{ Occupation; $n(\%)$} \\
\hline Housekeeper & $49(61.2)$ \\
\hline Formal worker & $11(13.8)$ \\
\hline Informal worker & $9(11.2)$ \\
\hline Retired & $4(5)$ \\
\hline Other & $7(8.8)$ \\
\hline \multicolumn{2}{|l|}{ Life habits } \\
\hline Exposed to tobacco; $n(\%)$ & $42(52.5)$ \\
\hline Time of exposure to tobacco (years); median & 33 \\
\hline Exposed to alcohol; $n(\%)$ & $29(36.3)$ \\
\hline Time of exposure to alcohol (years); median & 28 \\
\hline \multicolumn{2}{|l|}{ Consumption of fruits and vegetables per day; $n$ (\%) } \\
\hline 5 or more portions & $15(18.8)$ \\
\hline 4 or less portions & $65(81.2)$ \\
\hline \multicolumn{2}{|l|}{ Consumption of meats; $\mathrm{n}(\%)$} \\
\hline Beef/pork & $34(42.5)$ \\
\hline Poultry/fish & $15(18.7)$ \\
\hline Cold cuts & $4(5)$ \\
\hline Others & $25(31.3)$ \\
\hline Without data & $2(2.5)$ \\
\hline \multicolumn{2}{|l|}{ Sedentary; $n(\%)$} \\
\hline Yes & $34(42.5)$ \\
\hline No & $46(57.5)$ \\
\hline \multicolumn{2}{|l|}{ Frequency of physical activity; $n(\%)$} \\
\hline$\leq 1$ time per week & $3(8.8)$ \\
\hline 2 to 4 times per week & $11(32.4)$ \\
\hline$\geq 5$ times per week & $20(58.8)$ \\
\hline
\end{tabular}

SD: Standard deviation. 
Table 2. Personal and family background, current clinical and wound characteristics of 80 patients diagnosed with ulcer of venous etiology

\begin{tabular}{|c|c|}
\hline Variables & Value \\
\hline \multicolumn{2}{|l|}{ Clinical characteristics } \\
\hline \multicolumn{2}{|l|}{ Body mass index; $n(\%)$} \\
\hline Underweight & $1(1.2)$ \\
\hline Normal weight & $21(26.2)$ \\
\hline Overweight & $29(36.3)$ \\
\hline Obesity & $29(36.3)$ \\
\hline Body mass index; median & 27.6 \\
\hline \multicolumn{2}{|l|}{ Blood pressure; $n(\%)$} \\
\hline Normal & $18(22.5)$ \\
\hline Prehypertension & $44(55)$ \\
\hline Stage 1 hypertension & $11(13.7)$ \\
\hline Stage 2 hypertension & $7(8.8)$ \\
\hline \multicolumn{2}{|l|}{ Ankle/arm index (Yao); $n(\%)$} \\
\hline$<0.7$ & $1(1.2)$ \\
\hline 0.7 to 1.3 & $43(53.8)$ \\
\hline 1.4 and more & $6(7.5)$ \\
\hline Without data & $30(37.5)$ \\
\hline Ankle/arm index; Average $\pm \mathrm{SD}$ & $1.13 \pm 0.16$ \\
\hline \multicolumn{2}{|l|}{ Antecedents; $n(\%)$} \\
\hline High blood pressure & $51(63.7)$ \\
\hline Diabetes Mellitus & $14(17.5)$ \\
\hline Hypercholesterolemia or hypertriglyceridemia & $25(31.3)$ \\
\hline Varicose veins & $69(86.3)$ \\
\hline Surgeries due to venous disease & $21(26.3)$ \\
\hline Family background of venous disease & $45(56.3)$ \\
\hline Personal background of UVE & $53(66.3)$ \\
\hline \multicolumn{2}{|l|}{ Cicatrization time of prior UVE; $n(\%)$} \\
\hline 0 to 4 months & $21(39.6)$ \\
\hline 5 to 12 months & $19(35.8)$ \\
\hline 13 months and more & $11(20.8)$ \\
\hline Without data & $2(3.8)$ \\
\hline Cicatrization time of prior UVE in months; Median & 5 \\
\hline \multicolumn{2}{|l|}{ Characteristics of current wound } \\
\hline \multicolumn{2}{|l|}{ Antiquity of current wound; $n(\%)$} \\
\hline$\leq 3$ months & $31(38.7)$ \\
\hline a 12 months & $21(26.3)$ \\
\hline$>12$ months & $28(35)$ \\
\hline \multicolumn{2}{|l|}{ Limb affected; $n(\%)$} \\
\hline Lower left limb & $47(58.8)$ \\
\hline Lower right limb & $33(41.2)$ \\
\hline
\end{tabular}


Table 2. Personal and family background, current clinical and wound characteristics of 80 patients diagnosed with ulcer of venous etiology (cont.)

$\begin{array}{lc}\text { Variables } & \text { Value } \\ \text { Location of current wound } & \\ \quad \text { Internal malleolar } & 27(33.7) \\ \text { External malleolar } & 6(7.5) \\ \text { Dorsal } & 6(7.5) \\ \text { Supra-malleolar } & 8(10) \\ \text { Distal third } & 15(18.8) \\ \text { Medial third } & 16(20) \\ \text { Proximal third } & 2(2.5) \\ \text { Number of recurrences; } n(\%) & \\ \text { O times } & 0(0) \\ 1 \text { time } & 8(15) \\ 2 \text { to } 3 \text { times } & 26(49.1) \\ 4 \text { times and more } & 19(35.9) \\ \text { Number of recurrences; average } \pm \text { SD } & 3.87 \pm 3.72\end{array}$

SD: Standard deviation

The cicatrization process was analyzed during all the evaluation times. Graphic 1 shows that change in wound size was bigger between T0 and $\mathrm{T} 1$, noting a decrease of nine points in the median score of the Resvech scale, meaning a change of compromise from moderate to slight; in T2, 25\% of the participants had healed and in T4, process stagnation was observed in patients with large wounds and with associated complications; at the same time, maintained inflammation of the affected lower limb and decompensation in their comorbidities were evidenced.

Upon analyzing cicatrization in function of time, it was observed that $48.8 \%$ of the patients $(52.5 \%$ of the women and $38.1 \%$ of the men, $p \leq 0.01$ ) had cicatrization success of the wound in a maximum time of 90 days. Wounds located on the dorsal remained for a longer time (median of 113.5 days) and wounds located in the anterior median third of the limb healed faster (median of 48 days).

The Kaplan-Meier method was used to obtain the estimations of the cicatrization process from each of the evaluations of the 80 patients, of which 71 had cicatrization and nine were censored (due to loss and due to not presenting the event upon ending the follow up). The variable of follow up time had abnormal behavior of the data (ShapiroWilk test $<0.0001$ ). It was found that the median of the cicatrization time was 78 days (minimum $=14$ days and maximum $=264$ days, percentile $25=48$ days and percentile $75=130$ days). Graphic 2 shows the cicatrization in function of time, which exposes that the probability of an individual to healing increases over time.

To establish the variables that should be entered into the Cox proportional risk model, comparison was made of the cicatrization time with the variables dichotomized through the Logrank and Wilcoxon-Breslow tests. The first test was used when the graphics suggested differences in survival of the groups compared, the second test was used to find the statistic when it was not possible to establish that difference among groups. The variables shown in Table 4 were finally selected.

Thereafter, the Cox proportional risk model was conducted to study the multivariate effect on cicatrization over time. Several models were run, according to the variables candidates for 
Table 3. Basal evaluation of the wound in 80 patients diagnosed with ulcer of venous etiology according to the Resvech 2.0 instrument

\begin{tabular}{|c|c|}
\hline \multirow{2}{*}{\multicolumn{2}{|c|}{ Dimension of the principal lesion; $n(\%)$}} \\
\hline & \\
\hline $\begin{array}{l}\leq 15.9 \mathrm{~cm}^{2} \\
16-63.9 \mathrm{~cm}^{2} \\
64 \mathrm{~cm}^{2} \text { and more }\end{array}$ & $\begin{array}{c}48(60) \\
23(28.8) \\
9(11.2)\end{array}$ \\
\hline Dimension in $\mathrm{cm}^{2}$ of the principal lesion; Median & 12.13 \\
\hline \multicolumn{2}{|l|}{ Dimension of the principal satellite wound; $n(\%)$} \\
\hline $\begin{array}{l}\leq 4 \mathrm{~cm}^{2} \\
>4 \mathrm{~cm}^{2}\end{array}$ & $\begin{array}{l}27(77.1) \\
8(22.9)\end{array}$ \\
\hline \multicolumn{2}{|l|}{ Depth of affected tissue; $n(\%)$} \\
\hline $\begin{array}{l}\text { Dermis or epidermis } \\
\text { Subcutaneous tissue } \\
\text { Muscle }\end{array}$ & $\begin{array}{l}62(77.5) \\
17(21.3) \\
0(0)\end{array}$ \\
\hline Bone and annexed tissues & $1(1.2)$ \\
\hline \multicolumn{2}{|l|}{ Stage of the edges; $n(\%)$} \\
\hline Diffuse & $9(11.3)$ \\
\hline Defined & $51(63.7)$ \\
\hline Damaged & $18(22.5)$ \\
\hline Thickened & $2(2.5)$ \\
\hline \multicolumn{2}{|l|}{ Wound bed tissue; $n(\%)$} \\
\hline Epithelial & $3(3.8)$ \\
\hline Granulation & $32(40)$ \\
\hline Slough in wound bed & $41(51.2)$ \\
\hline Necrotic & $4(5)$ \\
\hline \multicolumn{2}{|l|}{ Amount of exudate; $n(\%)$} \\
\hline Moist & $7(8.8)$ \\
\hline Wet & $24(30)$ \\
\hline Saturated & $25(31.2)$ \\
\hline Dry or with exudate leak & $24(30)$ \\
\hline \multicolumn{2}{|l|}{ Characteristics of Infection/inflammation; $n$ (\%) } \\
\hline Pain & 76 (95) \\
\hline Perilesional erythema & $66(82.5)$ \\
\hline Perilesional edema & $71(88.7)$ \\
\hline Increased temperature & $6(7.5)$ \\
\hline Exudate that increases & $40(50)$ \\
\hline Purulent exudate & $3(3.7)$ \\
\hline Friable or bleeding tissue & $27(33.7)$ \\
\hline Stagnant wound & $74(92.5)$ \\
\hline Biofilm tissue & $1(1.2)$ \\
\hline Odor & $5(6.2)$ \\
\hline Hyper-granulation & $0(0)$ \\
\hline Wound that increases in size & $65(81.2)$ \\
\hline Satellite lesions & $35(43.7)$ \\
\hline Paleness of the tissue & $5(6.2)$ \\
\hline
\end{tabular}




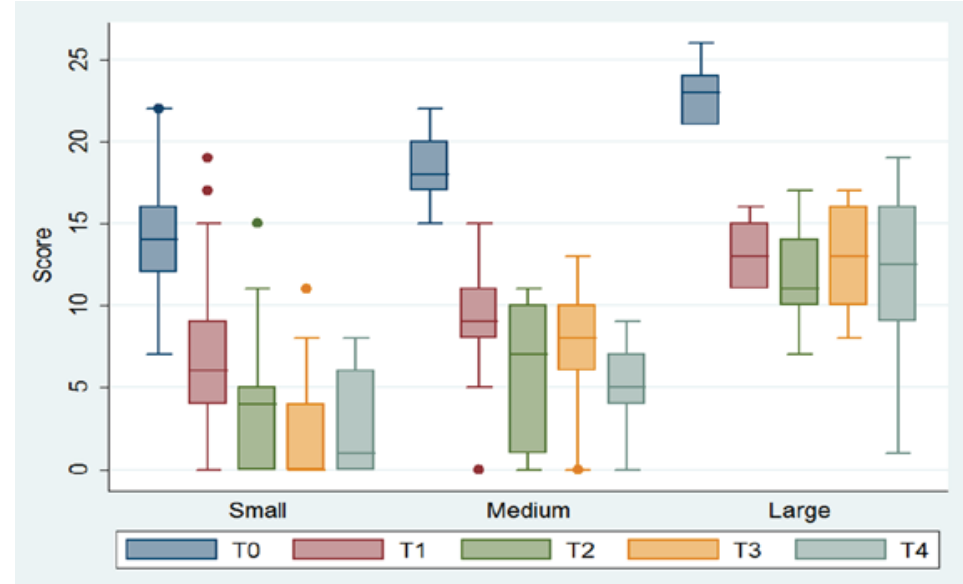

Graphic 1. Evolution of cicatrization of 80 patients diagnosed with ulcer of venous etiology, according to the moment of measurement and size of wound

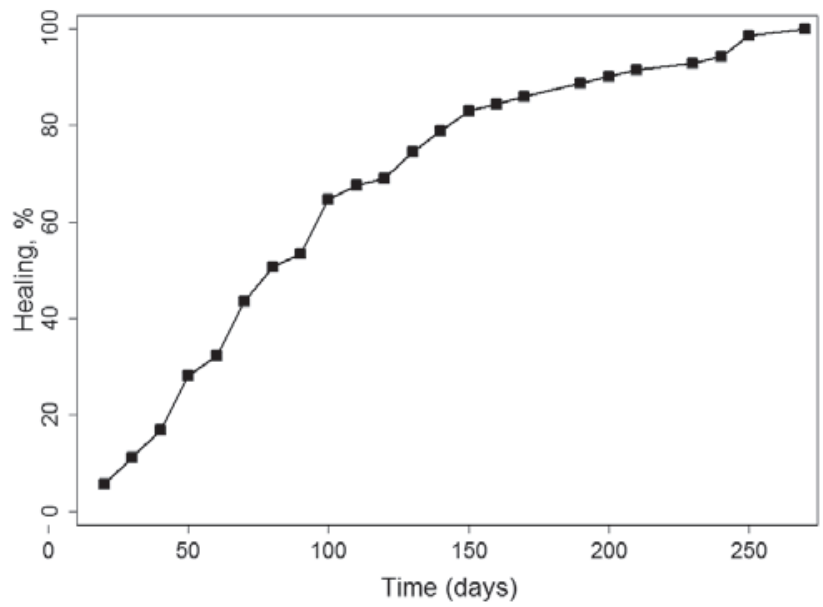

Graphic 2. Cicatrization in function of time of 80 patients diagnosed with ulcer of venous etiology

Table 4. Variables with potential to be included in the Cox proportional risk model of 80 patients diagnosed with ulcer of venous etiology

\begin{tabular}{|c|c|c|}
\hline Variable & Test used & $p$ value \\
\hline Slight compromise of the wound & Logrank & $\leq 0.0001$ \\
\hline Small wound size & Logrank & $\leq 0.0001$ \\
\hline Experience of the nurse $\geq 5$ years & Logrank & 0.0158 \\
\hline Socioeconomic level $\geq 3$ & Logrank & 0.0239 \\
\hline No antecedents of treatment & Wilcoxon-Breslow & 0.0372 \\
\hline Time of the wound $\leq 6$ months & Logrank & 0.0461 \\
\hline Age $\leq 65$ years & Logrank & 0.0584 \\
\hline Gender male & Wilcoxon-Breslow & 0.1017 \\
\hline
\end{tabular}


input into the model and the final risk model was constructed with the Breslow method. The statistical software showed that the model is adequate $(\chi 2<0.0001)$. The Cox proportional risk model (Table 5) showed that cicatrization in all the evaluation moments is affected by the variables of the lesion's degree of compromise, nurse's experience, and socioeconomic level; age, wound antiquity, and gender were included, given the individual effect and prior knowledge of modification these variables exert on the cicatrization times. As noted in Table 5, the cicatrization rate of the individuals with slight compromise of the wound was 1.7 times faster with respect to those who had high compromise, throughout the study time and upon adjusting for the other variables. The cicatrization rate of those treated by a nurse with five years and more de experience was double $(H R=2.1)$ compared with those who were cared by a nurse with less experience. Likewise, those in socioeconomic levels one or two took twice the time to heal in relation to those from socioeconomic levels three and above.

Table 5. Cox proportional risk model of 80 patients diagnosed with venous ulcer

\begin{tabular}{llcccc}
\multicolumn{1}{c}{ Variable } & HR & Std. Err. & $\mathbf{z}$ & $\boldsymbol{p}$ value & 95\% $\mathbf{C l}$ \\
Slight compromise of the wound & 2.7 & 0.8 & 3.47 & 0.001 & $1.5-4.7$ \\
Experience of the nurse $\geq 5$ years & 2.1 & 0.7 & 2.23 & 0.025 & $1.1-4.0$ \\
Socioeconomic level $\geq 3$ & 2.0 & 0.6 & 2.34 & 0.019 & $1.1-3.6$ \\
Time of wound $\leq 6$ months & 0.9 & 0.3 & -0.24 & 0.808 & $0.5-1.8$ \\
Age $\leq 65$ years & 1.7 & 0.5 & 1.85 & 0.064 & $0.9-2.9$ \\
Gender male & 0.7 & 0.2 & -1.32 & 0.187 & $0.3-1.2$ \\
\hline
\end{tabular}

HR: Hazard ratio; Std. Err.: Standard Error; Cl: confidence interval

\section{Discussion}

In this study, participants with UVE were mostly females and were between the sixth and seventh decade of life, which has been described in literature. ${ }^{(5,17)}$ Marques $^{(18)}$ stated that female prevalence is due to gestational disorder that lead to post-thrombotic syndrome, besides the high prevalence of varicose veins, although some studies ${ }^{(10,19)}$ described among their participants a proportion of UVE in men above $50 \%$.

This study found a cicatrization rate of $48.8 \%$ in 90 days or less. In light of this, Finlayson ${ }^{(20)}$ compared the effectiveness of some methods in treating ulcers of venous etiology and found a 10week cicatrization median for participants using compression bandages and 14 weeks for those using compression stockings; also, Lozano(21) proposed cicatrization times of 12 weeks when using multilayered compression bandage. In a systematic review, Borges ${ }^{(22)}$ describes better cicatrization times with the use of compression bandage with $30 \%$ healing of the wound in the first two weeks of treatment. The author also proposes that cicatrization times are dependent on the treatment used and characteristics of the wound. Regarding the stage of wound compromise, this study found prolonged cicatrization times when wound size was large and compromise was high. With relation to this, Finlayson ${ }^{(20)}$ also described more delay in cicatrization in wounds larger than $10 \mathrm{~cm}^{2}$, as in other studies ${ }^{(23,24)}$ referring to differences in cicatrization and prognosis when the wounds were bigger and had greater compromise on the tissue.

This study found that the experience of treating nurses determines the time and cicatrization success. Studies, like that by Adderley, ${ }^{(25)}$ have compared general nurses with specialists 
in treating wounds and have shown that the latter are more precise in identifying the lesion, diagnostic judgment, and suitability for treatment. In this regard, Ylonen ${ }^{(26)}$ described in a literature review that the treating nurses have knowledge gaps concerning the evaluation, physiology, and healing process, hence, the author cites the need to increase knowledge and nursing care, as well as continuous education to the patient.. With relation to the aforementioned, Zarchi(27) warns on the treatment that the compression event should also be taught and perfected. Likewise, this author identified substantial variation in the pressure made by elastic and inelastic bandages when measuring the pressure exerted by different professionals who placed the bandages, finding that they had variable underestimations and overestimations in the pressure exerted. The author added that, because of its efficacy, wellestablished compressive therapy is the essential intervention to treat ulcers of venous etiology.

This research found better cicatrization times in participants from higher socioeconomic levels. With respect to this, Selvaraj ${ }^{(10)}$ exposed that patients belonging to low and middle socioeconomic levels, with non-professional occupations and who remained on their feet for extended periods or seated because of household work, agricultural work, and informal work, favored development of venous disease that in time could be complicated with UVE. Similarly, Marques ${ }^{(18)}$ found more prevalence of UVE in individuals from low socioeconomic levels, low income, and low educational level; some of these findings were also present in this research. To end, other risks exist associated to poor cicatrization, among them high body mass indices, poor nutrition, dietary intake low in fruits and vegetables and poor practice of physical activity. ${ }^{(28)}$ In fact, our findings also showed high prevalence of these risk factors in the participants.

This study concludes that cicatrization of UVE in a time $\leq 90$ days was associated to slight compromise of the wound, which involves its size and stage of tissue affectation, the expertise of the treating nurse, and the socioeconomic level $\geq 3$. According to these factors, and considering that UVE are a multi-causal manifestation, we need to promote the relationship between knowing and doing in caring for individuals with ulcer of venous etiology, and it is recommended to emphasize during the formation of future nurses and during continuous education of those who are already professionals the theoretical and practical settings of prevention and treatment of UVE, which will contribute to improving the quality of care for the person with this health problem. ${ }^{(29)}$

Limitations. Some of the data of the evaluations was obtained from the clinical history or comments by the treating nurse, which can offer variation in the results. Although various confounding factors were considered and multivariate analyses were performed with adjustments by the risk factors established, the possibility exists that using different technological dressings to favor the wound bed affects the results.

Acknowledgments. The author thank the participants and nurses from the wound clinics, especially Ana Lucía Pérez Mesa and her team; Professor Juan Fernando Saldarriaga Franco for his methodological accompaniment; the Epidemiology research group of the National Faculty of Public Health at Universidad de Antioquia and the CODI Sustainability Strategy for its economic support. 


\section{References}

1. Nettel F, Rodriguez N, Nigro J, González M, Conde A, Muñoa A, et al. Primer Consenso Latinoamericano de Úlceras Venosas. Rev. Mex. Angiol. 2013; 41(3):95-126.

2. Chayamiti EM, Caliri MH. Úlcera por pressão em pacientes sob assistência domiciliária. Acta Paul. Enferm. 2010; 23:29-34.

3. Crawford JM, Lal BK, Durán WN, Pappas PJ. Pathophysiology of venous ulceration. J. Vasc. Surg. Venous Lymphat. Disord. 2017; 5(4):596-605.

4. González RV, Verdú J. Quality of life in people with venous leg ulcers: an integrative review. J. Adv. Nurs. 2011; 67(5):926-44.

5. Marola S, Ferrarese A, Solej M, Enrico S, Nano M, Martino V. Management of venous ulcers: State of the art. Int. J. Surg. 2016; 33:S132-S4.

6. Comerota A, Lurie F. Pathogenesis of venous ulcer. Semin Vasc Surg. 2015;28(1):6-14.

7. Raffetto JD. Pathophysiology of chronic venous disease and venous ulcers. Surg. Clin. North Am. 2018; 98(2):33747

8. Fukaya E, Margolis D. Approach to diagnosing lower extremity ulcers. Dermatol. Ther. 2013; 26:181-6.

9. Ribu L, Birkeland K, Hanestadc B, Moumd T, Rustoen T. A longitudinal study of patients with diabetes and foot ulcers and their-health-related quality of life: wound healing and quality-of-life changes. J. Diabetes Complications. 2008; 22:400-7.

10. Selvaraj D. Kota A, Premkumar P, Stephen E, Agarwal S. Socio-demography and clinical profile of venous ulcers. Wound Med. 2017; 19:1-4.

11. Marinel. J, Verdú J. Conferencia Nacional de Consenso sobre las Ulceras de la Extremidad Inferior (C.O.N.U.E.I.). Documento de consenso 2018. 2nd ed. Madrid: Ergon; 2018. P.35.

12. Gordon P, Widener JM, Heffline M. Venous leg ulcers: Impact and dysfunction of the venous system. J. Vasc. Nurs. $2015 ; 33(2): 54-9$.

13. Pannier F, Rabe E. Differential diagnosis of leg ulcers. Phlebology. 2012; 28(1):55-60.

14. Finlayson $\mathrm{K}, \mathrm{Wu} \mathrm{M}-\mathrm{L}$, Edwards $\mathrm{HE}$. Identifying risk factors and protective factors for venous leg ulcer recurrence using a theoretical approach: A longitudinal study. Int. J. Nurs. Stud. 2015; 52(6):1042-51.

15. González RV, López WJ, Roa KT. Epidemiología de lesiones de piel relacionadas con el cuidado: estudio de la prevalencia en Colombia. Referência. 2017; 4(15):65-72.

16. Restrepo JC. Instrumentos de monitorización clínica y medida de la cicatrización en úlceras por presión (UPP) y úlceras de la extremidad inferior (UEI). Desarrollo y validación de un índice de medida [Doctoral Thesis]. Alicante: Universidad de Alicante; 2010.

17. Edwards H, Finlayson K, Skerman H, Alexander K, Miaskowski C, Aouizerat B, et al. Identification of symptom clusters in patients with chronic venous leg ulcers. J. Pain Symptom Manage. 2014; 47(5):867-75.

18. Marques E, Bonetti W, Aragao V, Aderval J, Bitencurt L. Ulcer Due to Chronic Venous Disease: A sociodemographic study in northeastern Brazil. Ann. Vasc. Surg. 2013; 27:571-6.

19. Labropoulos N, Wang ED, Lanier ST, Khan SU. Factors associated with poor healing and recurrence of venous ulceration. Plast. Reconstr. Surg. 2012; 129(1):179-86.

20. Finlayson KJ, Courtney MD, Gibb MA, O'Brien JA, Parker CN, Edwards HE. The effectiveness of a four-layer compression bandage system in comparison with Class 3 compression hosiery on healing and quality of life in patients with venous leg ulcers: a randomised controlled trial. Int.Wound J. 2014; 11(1):21-7.

21. Alexandre S, Arola N, Jovè M, Blanco J. Uso de terapias alternativas en la cicatrización de úlceras de etiología venosa. La cromoterapia. Gerokomos. 2012; 23(4):185-8.

22. Borges EL, Caliri MH, Haas VJ. Systematic review of topic treatment for venous ulcers. Revisión sistemática del tratamiento tópico de la úlcera venosa. Rev. Latino-Am. Enfermagem. 2007;15(6):1163-7. 
23. Margolis DJ, Allen-Taylor L, Hoffstad O, Berlin JA. The accuracy of venous leg ulcer prognostic models in a wound care system. Wound Repair Regen. 2004;12(2):163-8.

24. Meaume S, Couilliet D, Vin F. Prognostic factors for venous ulcer healing in a non-selected population of ambulatory patients. J. Wound Care. 2005;14(1):31-4.

25. Adderley UJ, Thompson C. A comparison of the management of venous leg ulceration by specialist and generalist community nurses: A judgement analysis. Int. J. Nurs. Stud. 2016; 53:134-43.

26. Ylönen M, Stolt M, Leino-Kilpi H, Suhonen R. Nurses' knowledge about venous leg ulcer care: a literature review. Int. Nurs. Rev. 2014; 61(2):194-202.

27. Zarchi K, Jemec GB. Delivery of compression therapy for venous leg ulcers. JAMA Dermatol. 2014; 150(7):730-6.

28. McDaniel JC, Kemmner KG, Rusnak S. Nutritional profile of older adults with chronic venous leg ulcers: A pilot study. Geriatr. Nurs. 2015; 36(5):381-6.

29. Sousa ATO, Formiga NS, Oliveira SHS, Torres GVT, Costa MML, Soares MJGO. Validating an instrument to assess nurse knowledge related to preventing and treating individuals with venous ulcer. Invest. Educ. Enferm. 2016; 34(3): 433-43. 